\title{
Promoting autonomous learning in English through the implementation of Content and Language Integrated Learning (CLIL) in science and maths subjects
}

\author{
Putu Fika Andriani * , Ni Nyoman Padmadewi, I Gede Budasi \\ Universitas Pendidikan Ganesha, Singaraja, Bali, Indonesia
}

\begin{abstract}
Autonomous learning is a concept in which the learner has the ability to take charge of their own learning. It becomes a notable aspect that should be perceived by students. The aim of this research is for finding out the strategies used by grade two teachers in Bali Kiddy Primary School to promote autonomous learning in English through the implementation of Content and Language Integrated Learning in science and maths subjects. This study was designed in the form of descriptive qualitative study. The data were collected through observation, interview, and document study. The result of the study shows that there are some strategies of promoting autonomous learning in English through the implementation of CLIL in Science and Maths subjects. Those strategies are table of content training, questioning \& presenting, journal writing, choosing activities, and using online activity. Those strategies can be adopted or even adapted as the way to promote autonomous learning in English subject.
\end{abstract}

Key words. autonomous learning; CLIL

\section{Introduction}

Learning languages other than our mother tongue is the proof that human being has tried to cross one of the boundary in communication called language. English is one of the language which need to be mastered in order to communicate in this globalization era. Related with that fact, many strategies have been found in order to teach English as a second or foreign language. However, sometimes it is not only about how the teacher use those strategies to teach the language but also about the students' effort to learn that language. Being successful in learning is not merely about score. It is about making the effort to learn something. The same thing goes for language learning. No matter how much students have learnt at school, in the future they will need to learn other things by

*Corresponding author: andrianiputufika@gmail.com 
developing and relating new things with their background knowledge. The point is, sooner or later they will have to study on their own, and they need to learn how to learn. "Critically aware learners" are those who will do well in a fast-changing world [1]. Thus, in this fast changing world, there is a need to shape our students to be autonomous learners as they will need the skill not only for language learning, but also for variety of work and environments in their future lives. Students need to become capable in adapting and developing strategies to do individual learning, so they have critical awareness about what and how they should learn. The aim of this research is for finding out the strategies used by grade two teachers in Bali Kiddy Primary School to promote autonomous learning in English through the implementation of Content and Language Integrated Learning in science and maths subjects.

Autonomous learning is defined as "the ability to take charge of one's own learning" [2]. Other definition emphasizes that autonomous learning itself is an act of learning that consciously motivates learners to make best decisions about their own learning [3]. Learning can be more focused and purposeful for students when they are involved in decision making processes regarding their own language competence [4]. There are some reasons for helping learners to take on more responsibility for their own learning. The first reason is because of the learning effectiveness. It is improved when learners take charge of their own learning. It happens because the learners learn what they want to learn. The second reason is the learners who take responsibility for their own learning can continue learning outside the classroom, and the third reason is that learners who know how to learn can transfer their learning strategies to other subjects [5]. On the other hand, Content-andLanguage-Integrated-Learning (CLIL) refers to the use of a language other than the students' mother tongue as the medium of instruction in an educational setting [6].

There are some researches which focused in strategies to promote autonomous learning. Padmadewi mentioned some techniques to promote autonomous learning in the classroom for young learners. Those techniques, namely maximizing the use of reading log; using reading rocket system, and using reading response journal system [7]. Hafner \& Miller described the potential of the collaborative digital video project in a technological learning environment to provide students with opportunities to exercises their capacities as autonomous learners [8]. In their view an autonomous learner is not only the one who has intrinsic motivation and learns outside the classroom with no need for support from the teacher, but also develop in the structured learning environment of the classroom and become part of the pedagogical objectives of a language course. Ramamuruthy and Rao found that the use of smartphone could boost learners' critical thinking, creative thinking, communication, and collaboration skills [9]. The result showed that learners have moved toward autonomous learning, however, they were still reliant on the teachers to achieve their learning goals. The used journal writing [10] and weekly report [11] also can stimulate students' autonomy in writing as the students are given an opportunity to reflect on their new knowledge, ask questions about unclear ideas, and explore the value of question asking itself.

Those researches show that autonomous learning can provide the students with a better chance for learning foreign language, in this case, English. Students' English proficiency was significantly and positively related to their learner autonomy [12]. However, there is a condition where the autonomous learning in English can be promoted while learning other subjects which use English as the language instruction. CLIL provides an intensive chance to use English not only for the language but also for the subject content, such as science and maths. CLIL become the platform for the students to use English, and the need to master the content in the subjects, in this case, maths and science, can be used as the tools to promote autonomous learning in English, as English is the language instruction of those subjects. By being autonomous learners, the students can take responsibility for their own 
learning. Moreover, when the students are armed with the knowledge of how to learn, they can transfer their learning strategies to other subjects.

\section{Research method}

This research was designed in the form of a descriptive qualitative study. The data were collected through classroom observations, and document study, and then interviews with the teachers were conducted to obtained clarification regarding the result of observation. Finally the data were analysed descriptively. The observation was conducted three times in each subject. It was meant to find out the strategies to promote autonomous learning in Maths and science class. The interviews were conducted to confirm the result of observation to the teachers. Document study was done to support the result of the interview and observation. The subjects of this study were 20 students of grade 2, and 2 teachers who teach Science and Maths in Bali Kiddy Primary School.

\section{Findings and discussion}

The findings in this study revealed that there are five strategies used for promoting autonomous learning in science and maths class. Four strategies were used by the science teacher to promote autonomous learning in English. Those teaching strategies namely (a) Table of Content Training, (b) Questioning \& Presenting, (c) Journal Writing, and (d) Choosing Activities. Meanwhile, in maths subject the teacher use educational web for online learning as the way to promote autonomous learning in English. Those strategies are commonly used by any teachers in the classroom. However, the science and maths teachers in Bali Kiddy Primary School designed those activities to train the students so they are able to do self-directed study.

Being able to read and use table of content is a simple but meaningful skill. By training the young learners to read and find the information through table of content, the teacher believed that it would provide guidance for them in their learning. This skill is useful when the students do independent study at home. The teacher wanted the students to realize that all books have parts and each part contains information for the reader. They can find the information by themselves in the book only if they know how to find it. In other words, by having this skill the students can learn how to learn. It is not only about bring and open the book based on teacher's instruction. The teacher wanted the young learners to have the awareness that their books are actually the assistant for their learning activity, and they do not need to wait for teachers or other people to help them to study. This skill is useful when the students want to do independent learning.

Questioning is the tool which is used by grade two teacher in Bali Kiddy Primary School to trigger the students' curiosity. The questions are expected to stimulate the students to use English and communicate their thought. Presentation activities gives the students a chance to perform in front of peers and teachers. The students usually just simply present the result of their work or demonstrate something to teach their friends. When the students are presenting something in front of their friends, they take the responsibility as the one who know-it-all, and are ready for the audience's questions and responses. Besides, they are stimulated to show more effort in order to perform better.

The next strategy used by the science teacher to promote autonomous learning in English is by writing science journal. The teacher asked the students to write down what they had learnt in their science class regularly. This journal was made as a project. The students were challenged to make the journal as informative and interesting as possible. The science teacher provided them with opportunities to modify and adapt classroom tasks. 
They were given choices about how they wanted to make the journal. They could make illustration, table, diagram, or mind map. Figure 1 shows the example of student's journal. It shows that the student made the journal in the form of simple diagram along with its illustration.

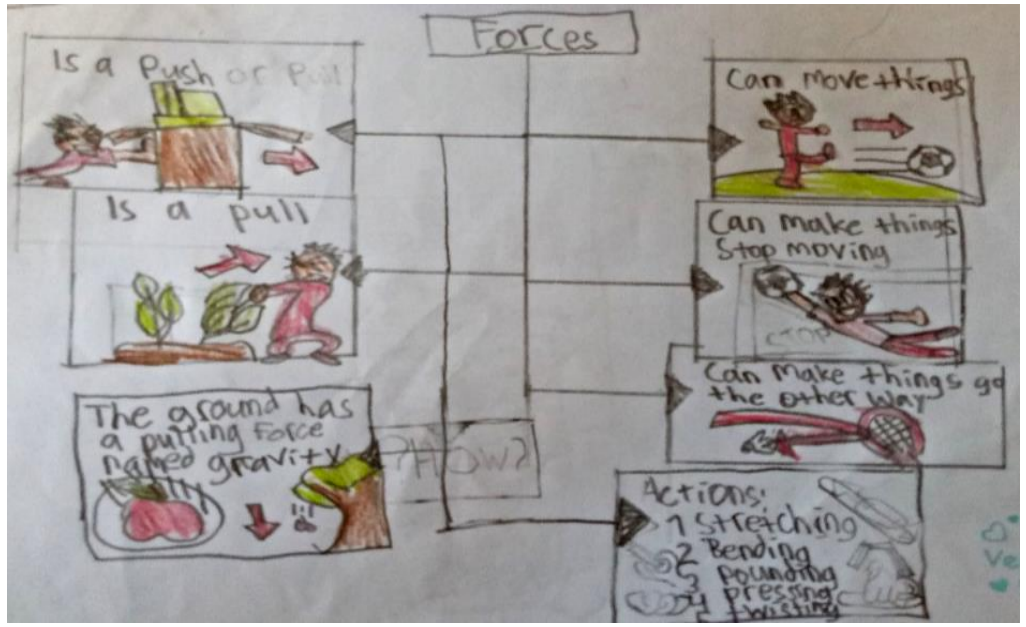

Fig. 1. Example of student's journal.

By making the journal writing as a project, the students could show their conscious effort to learn and find out more information and vocabulary to be written on the journal. They were free to add information about the science topic from various sources. It could be from other books or internet sources. Students can set their own goal about how informative and interesting their journal will be. This journal project can also train their skill in taking note. Teaching learners to take notes helps them to be independent learner [13]. Making their own note Figure 2 below shows the steps of training the students to write the science journal in order to promote autonomous learning in English.

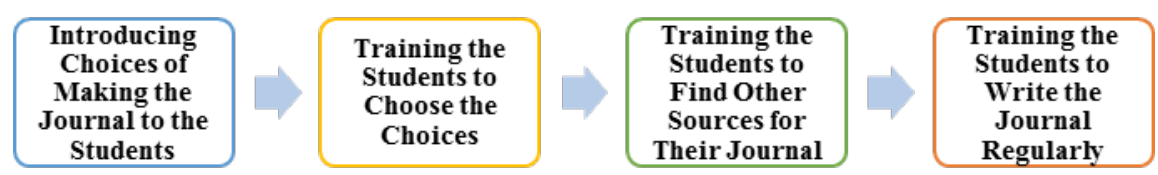

Fig. 2. Step of training the students to make the journal.

By letting the students to make choice, the teacher trained the students to develop their autonomy in learning. They made the choice and be responsible toward the choice they made. The feeling of success can bring confidence to the students; meanwhile, the feeling of failure can lead to an evaluation in making choices. The reward for the students are given in the form of titles, such as "The best journal illustrator", or "The most informative journal".

The teacher also let the students to choose their activity based on their preference. In review time, the students could choose to study alone or with a group of friends. They could study by sitting on the floor or combining their tables together. Instead of asking the student to follow a similar learning procedure, the teacher let the students choose their own way in learning. The important aspect that should be emphasized here is the reason behind the choice. The students should know in what way they learn best. The choice made by the 
students should be the conscious act to study in the way which they know they can learn best. By doing so, the teacher not only promoting autonomous learning but also using differentiated instruction. That was done as the attempts to combine teaching and learning to a learner's unique strength and needs [14]. Letting the students to choose also means that the teacher involves the students in their own learning which gives the sense of ownership of their achievement.

The freedom of making choice and the feeling of being involved in the learning process can motivate the learner to their study. At the initial step in training the students to make choices, the teacher still need to supervise the students' choices, and communicate the reason or the benefit behind the choices which were introduced by the teacher. This was done in order to make sure that what the students want is what they need.

Different from the science teacher, the Maths teacher used online learning as the way to promote autonomous learning in English. There is a list of topics that can be chosen by the students in their online account which use English as the language instruction. The students can make choice regarding what topic/ what activity they want to do in their online account, and the teacher is still able to track the students' progress. Stars chart was used to give reward for the students only at the beginning of the online learning introduction. The chart can give stimulation to initiate the online learning and do self-directed study.

The online account can be accessed by the students at home or at school in the computer laboratory. It provides the students with easy access to various information and knowledge regarding the topic they want to learn. In other words, the online account becomes the platform for the students to do self-access in learning. The students were trained to be critical in analysing what they need to learn and doing the online learning independently, but the teachers still has the role in helping the students to master the maths concept in the classroom, and check their understanding toward the concept in maths subject.

In conclusion, the steps in promoting autonomous learning in both subjects and the analysis of both teaching techniques which are used in science and maths and are formulated in table 1 .

Table 1. Steps in Promoting Autonomous Learning in English through CLIL in Science and Maths Subjects.

\begin{tabular}{|c|c|c|}
\hline No. & Steps & Description \\
\hline 1 & $\begin{array}{c}\text { Giving choices to the } \\
\text { students }\end{array}$ & $\begin{array}{c}\text { The initial step of promoting autonomous learning is by } \\
\text { introducing students with choices. Teachers give a } \\
\text { chance for the students to see all possibilities for their } \\
\text { learning so they have the basic knowledge to do self- } \\
\text { direct in learning. The choices can be about what to } \\
\text { learn and how to learn it. }\end{array}$ \\
\hline 2 & $\begin{array}{c}\text { Training the students to } \\
\text { make a choice }\end{array}$ & $\begin{array}{c}\text { The second step of promoting autonomous learning in } \\
\text { Science and Maths subjects is stimulating the students } \\
\text { to make a choice. The freedom to make a choice and the } \\
\text { feeling of being involved in every decision related with } \\
\text { their study can motivate the learner to their study. }\end{array}$ \\
\hline 3 & $\begin{array}{c}\text { Training the students to } \\
\text { find learning sources }\end{array}$ & $\begin{array}{c}\text { The aim of training the students to find learning sources } \\
\text { is for stimulating the students' awareness that teacher is } \\
\text { not the only source of learning. The students are } \\
\text { expected to be able to find sources and learn from it. In } \\
\text { that way the students will learn how to learn }\end{array}$ \\
\hline 4 & $\begin{array}{c}\text { Habit formation in } \\
\text { reading and writing }\end{array}$ & $\begin{array}{c}\text { The fourth step is making the students getting used to } \\
\text { with all the activities that can shape them to be } \\
\text { autonomous learners. }\end{array}$ \\
\hline 5 & Establishing habit for & \begin{tabular}{c} 
Establishing habit for being autonomous learner is done \\
\hline
\end{tabular} \\
\hline
\end{tabular}




\begin{tabular}{|c|c|c|}
\hline & being autonomous learner & by giving reward in order autonomous learning activity \\
to be repeated.
\end{tabular}

\section{Closure}

Based on the result of the research, it can be seen that some common learning strategies can be designed to promote autonomous learning in English. Table of content training, questioning \& presenting, journal writing, choosing activities, and using online activity emphasize the students to make choice and take control of their own learning in science and maths. Control and responsibility are the combination through which the students can have the sense of belonging in learning. Through science and maths they consciously learn English as the language instruction of both subjects. As the need to be autonomous learner is inevitable in the global competition, the teacher should consider the strategies to promote autonomous learning not merely as strategies for teaching but as the mean to get the real meaning of learning.

\section{References}

1. J. Godwin, LLT, 15, 4-11 (2011)

2. H. Holec, Autonomy and foreign language learning, (Oxford, Pergamon, 1981)

3. J. Xu, ELT, A survey study of autonomous learning by Chinese non-English major post-graduates, 2, 25-32 (2009)

4. A. Littlejohn, ELT Journal, 39, 253-261 (1985)

5. G. Ellis, B. Sinclair, Learning to learn English, (Cambridge University Press, United Kingdom, 1989)

6. Dalton-Puffer, Discourse in content and language integrated learning (CLIL) classrooms, (2017)

7. N. N. Padmadewi, JESOC, 3, 45-52 (2016)

8. C. Hafner, L. Miller, LLT, 15, 68-86 (2011)

9. V, Ramamuruthy, S. Rao, MOJET, 3 (2015)

10. L. Kamberi, Proceeding, $1^{\text {st }}$ Annual International Interdisciplinary Conference. AIIC, Promoting learner autonomy in foreign language learning by using student journals, (2013)

11. Wardah, Nurwahida, Proceeding, The $62^{\text {nd }}$ TEFLIN International Conference 2015, Stimulating students' autonomy in writing through weekly report, (2015)

12. D. Davei, Asian EFL Journal, (2007)

13. F. Mollaei, M. Riasati, JSLTE, 1, 105-120 (2013)

14. D. Cruickshank, D. Jenkins, K. Metcalf, The act of teaching ( $4^{\text {th }}$ ed), (McGraw Hill, New York, 2006) 